\title{
Freedom of Navigation in a Post 9/11 World: Security and Creeping Jurisdiction
}

\author{
Stuart Kaye
}

\section{Introduction}

The phrase 'creeping jurisdiction' has been applied by a number of publicists to the gradual extension of State jurisdiction offshore in the law of the sea through the course of the twentieth century. ${ }^{1}$ The phrase aptly captures the nature of this change, as States have slowly increased their control over progressively wider areas. For example, in 1900, the width of the territorial sea would have been accepted as 3 to 4 nautical miles (nm). By UNCLOS II in 1961, the favoured proposal of $6+6 \mathrm{~nm}$ for the territorial sea and contiguous zone was only just short of achieving the required two-thirds majority of participating States. Under the current Convention on the Law of the Sea (LOSC), and confirmed by international practice, the territorial sea is now $12 \mathrm{~nm}$ wide. Similar observations could be made in respect of resource jurisdiction, with the emergence of the continental shelf with the Truman Proclamation in 1945, and the exclusive economic zone (EEZ) growing out of Latin American and African practice to be confirmed at UNCLOS III. ${ }^{2}$

It might have been thought that jurisdictional creep had ended with the conclusion of the $\mathrm{LOSC}^{3}$ in 1982, and such a conclusion would find support in the general lack of acceptance of States attempting to grab jurisdiction beyond what the Convention permits. Neither the Chilean 'presential sea'4 nor the Canadian

1 See eg J A Knauss, "Creeping Jurisdiction and Customary International Law (1985) - 15 ODIL 209; B Kwiatkowska, 'Creeping Jurisdiction beyond 200 nautical miles in the Light of the Law of the Sea Convention and State Practice' (1991) 22 ODIL 159.

2 The history of the width of the territorial sea, and the emergence of the continental shelf and EEZ has been ably recorded by a number of publicists: see R R Churchill and A V Lowe, The Law of the Sea (University of Manchester Press, Manchester 1999); C J Colombos, The International Law of the Sea (6th edn, Longman, London 1967).

3 The United Nations Convention on the Law of the Sea 1982, 1833 UNTS 396; (1982) 21 ILM1261.

4 See C C Joyner and P N de Cola, 'Chile's Presential Sea Proposal: Implications for Straddling Stocks and the International Law of Fisheries' (1993) 24 ODIL 99. 
extension of jurisdiction over the Grand Banks has received much in the way of international support. ${ }^{5}$ Rather than an extension of national jurisdiction to resolve the problems facing high seas marine living resources, the international community has thrown its energy into cooperative arrangements, facilitated by regional fisheries organizations.

However, this paper will consider whether contemporary practice may lead to a further creeping of jurisdiction, not in a further grab for resources, but in an effort by States to provide themselves with greater security from threats from the sea. It will examine contemporary and emerging practice in respect of maritime security, and address the question whether seeking greater control over security is the next generation of jurisdictional creep, and what erosion of existing freedoms might occur.

\section{Security Jurisdiction Under the LOSC}

The LOSC does not deal with security issues to a significant extent. It almost completely avoids consideration of the law of naval warfare, and references to security matters are not dealt with in a single location, but rather in the context of other matters. Such references as there are can be found concentrated in the context of the regime of innocent passage, where the coastal State may temporarily suspend innocent passage for the purposes of essential security protection, ${ }^{6}$ and where different activities are deemed 'to be prejudicial to the peace, good order or security of the coastal state' if they occur on board a foreign ship in the territorial sea of the coastal State.

Article 19 of the LOSC indicates the activities of a vessel that are considered inconsistent with a right of innocent passage:

1. Passage is innocent so long as it is not prejudicial to the peace, good order or security of the coastal State. Such passage shall take place in conformity with this Convention and with other rules of international law.

2. Passage of a foreign ship shall be considered to be prejudicial to the peace, good order or security of the coastal State if in the territorial sea it engages in any of the following activities:

(a) any threat or use of force against the sovereignty, territorial integrity or political independence of the coastal State, or in any other manner in

5 See P G G Davies and C Redgwell, 'The International Regulation of Straddling Fish Stocks' (1996) 67 BYIL 199; C C Joyner and A A von Gustedt, "The Turbot War of 1995: Lessons from the Law of the Sea' (1996) 11 IJMCL 425 .

${ }_{6}$ LOSC, Article 25(3) provides: 'The coastal State may, without discrimination in form or in fact among foreign ships, suspend temporarily in specified areas of its territorial sea the innocent passage. of foreign ships if such suspension is essential for the protection of its security, including weapons exercises. Such suspension shall take effect only after having been duly published.' A provision with similar effect extends the same right to an archipelagic State in respect of archipelagic waters where innocent passage may be exercised. See LOSC, Article 52(2).

$\Rightarrow$ LOSC, Articie 19 violation of the principles of international law embodied in the Charter of the United Nations;

(b) any exercise or practice with weapons of any kind;

(c) any act aimed at collecting information to the prejudice of the defence or security of the coastal State;

(d) any act of propaganda aimed at affecting the defence or security of the coastal State;

(e) the launching, landing or taking on board of any aircraft;

(f) the launching, landing or taking on board of any military device;

(g) the loading or unloading of any commodity, currency or person contrary to the customs, fiscal, immigration or sanitary laws and regulations of the coastal State;

(h) any act of wilful and serious pollution contrary to this Convention;

(i) any fishing activities;

(j) the carrying out of research or survey activities;

(k) any act aimed at interfering with any systems of communication or any other facilities or installations of the coastal State;

(l) any other activity not having a direct bearing on passage.

This list does not render passage undertaken by warships, or even squadrons of warships, contrary to innocent passage, nor does it permit a coastal State to exclude warships from its waters for failure to notify the coastal State or seek its authorization. This is supported by the view taken by the International Court of Justice in the Corfu Channel Case of the passage of the four British warships along the Channel that led to the damage to HM Ships Saumarez and Volage. ${ }^{8}$

It is notable that the LOSC permits a wider definition of 'security' than what might ordinarily inferred from the word alone. While the term security is typical linked to military security in most contexts, it is notable that the reach of the restrictions on activities deemed non-innocent for passage include a wider range of issues. In addition to essentially military activities such as weapons testing and threats of force, other matters which might be deemed harmful to the security of the sovereignty of the coastal State are also inconsistent with innocent passage. These include harm to the marine environment, through pollution or illegal fishing, the undermining of State quarantine and customs control, or the transmission of propaganda. This broader definition of security is not appropriate in all contexts, even within the LOSC, but it will be used within this chapter to deal with efforts by States based on protecting their interests to restrict freedom of navigation in their adjacent waters.

Freedom of navigation beyond the territorial sea has its origins in Hugo Grotius' response to the Spanish and Portuguese claims of control over the oceans and territories outside of Europe by virtue of the Papal Bull' and Treaty of

[ [1949] IC] Rep 3.

Bull Inter Caertera of Pope Alexander VI, done on 4 May 1493, reproduced at http://bullsburning.itgo.com/essays/Caetera.htm\#theBull. 
Tordesillas. ${ }^{10}$ These documents purported not only to give control over territory outside of Europe, but also provided for exclusive seaborne trading rights in the South Atlantic and Indian Oceans. ${ }^{11}$ In reaction to this assertion, Grotius produced his seminal work, Mare Liberum, asserting that the oceans were incapable of appropriation by tates, and that the ships of any State could journey anywhere on the world's oceans. ${ }^{12}$

In the modern law of the sea, freedom of navigation was equally perceived as important, and this status was reflected in the now superseded Geneva Conventions on the law of the sea. Freedom of navigation on the high seas was guaranteed in Article 2 of the Convention on the High Seas, ${ }^{13}$ with Article 3 of the Continental Shelf Convention ensuring that the status of waters above a State's continental shelf remained as high seas, and therefore enjoyed freedom of navigation. ${ }^{14}$ The 1982 LOSC maintains the approaches found in the Corfu Channel Case and the Geneva Law of the Sea Conventions.

Beyond the territorial sea, the LOSC also confirms there is freedom of navigation for all vessels. This is essentially applicable for the EEZ and high seas areas beyond it. Article 87 of the LOSC provides:

1. The high seas are open to all States, whether coastal or land-locked. Freedom of the high seas is exercised under the conditions laid down by this Convention and by other rules of international law. It comprises, inter alia, both for coastal and landlocked States:

(a) freedom of navigation;

(b) freedom of overflight;

(c) freedom to lay submarine cables and pipelines, subject to Part VI;

(d) freedom to construct artificial islands and other installations permitted under international law, subject to Part VI;

(e) freedom of fishing, subject to the conditions laid down in section 2

(f) freedom of scientific research, subject to Parts VI and XIII.

2. These freedoms shall be exercised by all States with due regard for the interests of other States in their exercise of the freedom of the high seas, and also with due regard for the rights under this Convention with respect to activities in the Area.

While the LOSC makes it clear there is freedom of navigation on the high seas, the same freedom is extended to the EEZ by Article 58(1):

In the exclusive economic zone all states, whether coastal or land-locked, enjoy, subject to the relevant provisions of this Convention, the freedoms referted to in article 87 of navigation and overflight and of the laying of submarine cables and pipelines, and other internationally lawful uses of the sea related to these freedoms, such as those associated

10 Treaty of Tordesillas, done at Tordesillas on 7 June 1494, ratified by Spain 2 July 1494, ratified by Portugal 5 September 1494: reproduced at http://www:yale.edu/lawweb/avalon/modeur/modool. hm. ${ }^{11}$ Colombos, above note 2; 48-49; H Caminos, 'Sources of the Law of the Sea' in R-J Dupuy and DVignes (eds), A Handbook of the New Law of the Sea (Martinus Nijhoff, Dordrecht 1991) 29, 64-65. 12 H Grotius, The Freedom of the Seas (Carnegie Endowment for International Peace, New York eprinted 1952). 13 Convention on the High Seas, 1958, 450 UNTS 82.

14 Convention on the Continental Shelf 1958,499 UNTS 311 with the operation of ships, aircraft and submarine cables and pipelines, and compatible with the other provisions of this Convention.

The right of freedom of navigation on the high seas and the EEZ is circumscribed by the notion of 'due regard' for the rights of others. As such, if a State is lawfully fishing, or engaged in exploration or exploitation of seabed resources, other States ought not prejudice or interfere with that activity in undertaking their rights. As such, it is clear that undertaking military exercises on the high seas and EEZ of another State would be subject to the non-interference with the rights of other users. 15

\section{(a) Military security}

A number of States have sought to apply restrictions on vessels navigating in their territorial waters or their vicinity for the purpose of safeguarding their security. Such measures have no explicit support within the LOSC, and implicit support only insofar as the Convention indicates that passage through the territorial sea ought not to prejudice international peace and security. The coastal State has the ability to regulate certain matters with respect to a vessel exercising a right of innocent passage, although these do not refer to security interests. ${ }^{16}$ Rather they are essentially limited to ensuring that the territorial sea remains an area where navigation is safe, criminal activity to avoid immigtation or customs control is prohibited, and unauthorized fishing and pollution do not occur.

The issue of military activities, including surveillance, in the EEZ of another State is one not directly dealt with in the LOSC. ${ }^{17}$ While the Convention makes it plain that military exercises and weaponry testing in the territorial sea of a coastal State would be contrary to the regime of innocent passage, there is no equivalent restriction articulated with respect to other maritime zones. However, neither is there any authorization with respect to such exercises, with there being no

15 See B H Oxman, "The Regime of Warships under the United Nations Convention on the Law of the Sea' (1984) 24 Virginia Journal of International Law 809

36 LOSC, Article 21 provides:

"The coastal state may adopt laws and regulations, in conformity with the provisions of this Convention and other rules of international law, relating to innocent passage through the territorial sea, in respect of all or any of the following:

(a) the safery of navigation and the regulation of maritime traffic:

(b) the protection of navigational aids and facilities and other facilities or installations;

(c) the protection of cables and pipelines;

(d) the conservation of the living resources of the sea;

(e) the prevention of infringement of the fisheries laws and regulations of the coastal state;

(f) the preservation of the environment of the coastal state and the prevention, reduction and control of pollution thereof;

(g) marine scentific research and hydrographic surveys;

(h) the prevention of infringement of the customs, fiscal, immigration or sanitary laws and regulations of the coastal state.'

${ }^{17}$ See eg G V Galdoresi and A G Kaufman, 'Military Activities in the Exclusive Economic Zone: Preventing Uncertainty and Defusing Conflict' (2002) 32 California Western Journal of International Law 253. 
inclusion of military exercises or related activities in the list of freedoms. The lack of direct reference to military activities is not fatal to the case for the conduct of such exercises in the EEZ of another State. The rights listed in Article 87(1) are by no means an exhaustive list, and are merely specifically enunciated examples. This is explicit in the use of the phrase 'inter alia'. Further, the freedoms of the high seas are described as being subject to the conditions set down in the LOSC and 'other rules of international law'. The use of this language makes it clear that the LOSC is not intended to be the only source of law in relation to the use of the high seas or EEZ.is

If the case for freedom to undertake military exercises in another State's EEZ can be made, it is clearly subject to some qualification. For this the crux of the issue will essentially turn on the meaning of the phrase 'with due regard'. This qualification is applied to high seas freedoms generally in Article 87(2), and it would seem logical that one must have due regard to the rights of others while navigating through the EEZ. 19

One issue that could be relevant in assessing the legitimacy of freedom of navigation for warships in the contiguous zone relates to whether passage by such a vessel might constitute a threat to international peace and security, and therefore be illegitimate and capable of being intercepted. The LOSC provides limited assistance through Article 88 which provides that ' $[t]$ he high seas shall be reserved. for peaceful purposes'.

A wide reading of this provision would, in theory, see great limitation of the uses of warships on the high seas, and the potential circumscription of all military activities. When read with the Preamble, which invokes the LOSC's role in the furtherance of peace and security in the world, ${ }^{20}$ it suggests that only peaceful uses of the sea are permissible. By extension this could be drawn into the EEZ, as Article 58 adopts the high seas freedoms in the LOSC, and explicitly includes Article 88 in this list. ${ }^{21}$ Similarly, the provisions with respect to marine scientific research under Part XIII of the LOSC indicate that marine scientific research can only be undertaken for peaceful purposes. ${ }^{22}$ A case could be made that military activity from the high seas or another State's EEZ was incompatible with the LOSC, because such an activity would be inconsistent with the peaceful purposes

${ }_{18}$ See also the discussion below note 25 . 19 See F Francioni, 'Peacetime Use of Force, Military Activities, and the New Law of the Sea' (1985)
18 Comell International Law Journal 203 at 215; see also M H Nordquist (ed), United Nations Convention on the Law of the Sea 1982: A Commentary (Martinus Nijhoff, Dordrecht 1993) 553-565. 20 The Preamble states in part; "Prompted by the desire to sertle, in a spirit of mutual understanding and co-operation, all issues relating to the law of the sea and aware of the historic significance of this Convention as an important contribution to the maintenance of peace, justice sind pronce of for all peoples of the world', and 'Believing that the codification and progressive developmegress the law of the sea achieved in this Convention will contribute to the strengthening development of co-operation and friendly relations anvention will contribute to the strengthening of peace, security equal rights and will prom relations among all nations in conformity with the principles of justice and equal rights and will promote the economic and social advancement of all peoples of the world, in accordance with the Purposes and Principles of the United Nations as set forth in the Charter'.

21 Galorisi and Kaufman, above note 17, 275-278. 22 LOSC, Article 240 provides: 'In the conduct of marine scientific research the following prin-
ciples shall apply: (a) marine scientific research shall be conducted exclusively for peaceful purposes.' to which use of high seas freedoms can be put. However, such an interpretation has not been favoured by many States or publicists. ${ }^{23}$ The San Remo Manual on Armed Conflicts at Sed, which sought to update and consolidate the law of armed conflict at sea, makes it clear that armed conflict at sea can take place on the high seas and, in certain circumstances, in the EEZ of a neutral State. ${ }^{24}$ The Manual provides that belligerents must have due regard to the uses to which another State may wish to put its EEZ, and avoid damage to the coastal State.

A better view is that the LOSC encourages the peaceful uses of the sea, but is lex generalis, which must be considered in the context of the lex specialis dealing with the use of force at international law. ${ }^{25}$ The legitimate use of force under the UN Charter, either in self-defence or pursuant to a Security Council resolution, should still be permissible in maritime areas, and not restricted by the LOSC. Such an interpretation is supported explicitly in Article 301 of the LOSC. ${ }^{26}$

Measures to assert a security jurisdiction typically centre on a requirement of notification of voyages by foreign warships, but in some cases by any foreign vessels, through the territorial sea or a wider zone based on jurisdiction added to the contiguous zone or even beyond. ${ }^{27}$ An example of this is the requirement asserted by China. ${ }^{28}$ Overall over 60 States have asserted extended rights, and the nature of their claims is summarized in Table 1, below.

There is no justification within the text of the LOSC that permits a jurisdiction based around security concerns to be included within the regime of the contiguous zone. The contiguous zone is dealt with in a single article, and does not refer to security directly, or even by implication. ${ }^{29}$

23 On this point see D J Attard, The Exclusive Economic Zone in International Law (Clarendon Press Oxford 1987) 75; F Orrego Vicuna, The Exclusive Economic Zone: Regime and Nature under International Law (Cambridge University Press, Cambridge 1989) 110-113; Galdorisi and Kaufman, above note 17, 274-276.

${ }^{24}$ L Doswald-Beck (ed), San Remo Manual on International Law Applicable to Armed Conflicts at Sea (Cambridge University Press, Cambridge 1995) para 10 at 8.

${ }^{25}$ See the Legality of the Threat or Use of Nuclear Weapons Advisory Opinion [1996] ICJ Rep 66, para 25.

${ }_{26}$ LOSC, Article 301 provides: 'In exercising their rights and performing their duties under this Convention, states parties shall refrain from any threat or use of force against the territorial integrity or political independence of any state, or in any other manner inconsistent with the principles of international law embodied in the Charter of the United Nations'.

${ }_{27}$ As is evident in Table 1, some States assert security zones even beyond the $24 \mathrm{~nm}$ contiguous zone. For example North Korea asserts a security jurisdiction up to $62 \mathrm{~nm}$ from its coast, and Syria to a distance of $41 \mathrm{~nm}$. These examples are unusual, with the great majority of States asserting such a jurisdiction linking it to the contiguous zone.

${ }^{28}$ Article 13 of the Law of the Territorial Sea and the Contiguous Zone of 25 February 1992 provides that the Chinese exercise jurisdiction over security within the contiguous zone, and seeks prior notification. This is rejected by the US as inconsistent with Article 33 of the LOSC, which has no reference to a security jutisdiction in respect of the contiguous zone.

29 LOSC, Arricle 33 provides: 'In a zone contiguous to its territorial sea, described as the contiguous zone, the coastal state may exercise the control necessary to: (a) prevent infringement of its customs, fiscal, immigration or sanitary laws and regulations within its territory or territoria sea; (b) punish infringement of the above laws and regulations committed within its territory or territorial sea'. 
Table 1: State Practice on Limitations to Navigation ${ }^{a}$

\begin{tabular}{|c|c|}
\hline State & Type of Rights Asserted \\
\hline Albania & Warships require prior special authorization \\
\hline Algeria & $\begin{array}{l}\text { Authorization must be obtained for warships } 15 \text { days prior to their } \\
\text { passage; exception: force majeure }\end{array}$ \\
\hline $\begin{array}{l}\text { Antigua and } \\
\text { Barbuda }\end{array}$ & Warships require prior authorization \\
\hline Bangladesh & $\begin{array}{l}\text { Warships require prior authorization; } \mathrm{CZ} \\
18 \mathrm{~mm} \text { Security interests }\end{array}$ \\
\hline Barbados & Warships require prior authorization \\
\hline Brazil & $\begin{array}{l}\text { Prohibition of boarding, searching and capturing of vessels in the EEZ; } \\
\text { military exercises and manoeuvres may be conducted in the EEZ only } \\
\text { with the consent of Brazil }\end{array}$ \\
\hline Bulgaria & $24 \mathrm{~nm}$ ('Control rights') \\
\hline Cambodia & $\begin{array}{l}\text { Control of all foreign activities on the continental shelf, irrespective } \\
\text { of their purpose; } \mathrm{CZ} 24 \mathrm{~nm} \text { Security interests }\end{array}$ \\
\hline Cape Verde & $\begin{array}{l}\text { Warships require prior authorization; prohibition of 'ron-innocent } \\
\text { use' of the EEZ, including weapons exercises }\end{array}$ \\
\hline China & $\begin{array}{l}\text { Requires prior notice for transports of waste in TS and EEZ; warships } \\
\text { require prior authorization; CZ } 24 \mathrm{~nm} \text { Security interests }\end{array}$ \\
\hline Congo & All ships require prior authorization \\
\hline Costa Rica & $\begin{array}{l}\text { Fishing vessels must announce their passage through the EEZ } \\
\text { beforehand }\end{array}$ \\
\hline Croatia & Warships must announce their passage; the number of warships is limited \\
\hline Denmark & $\begin{array}{l}\text { Warships and governmental ships are required to notify the Danish } \\
\text { authorities prior to their passage through territorial waters if that } \\
\text { involves passage through the Great Belt, the Samsø Belt or the } \\
\text { Øre Sound; prior authorization is required for more than three } \\
\text { warships passing through at the same time }\end{array}$ \\
\hline Djibouti & $\begin{array}{l}\text { Prior notice required of any passage of nuclear-powered ships and } \\
\text { ships carrying nuclear or other radioactive material }\end{array}$ \\
\hline Ecuador & 'Special area to be avoided' \\
\hline Egypt & $\begin{array}{l}\text { Warships have to announce their passage in advance; ships carrying } \\
\text { nuclear material or other hazardous substances require prior } \\
\text { authorization; CZ } 24 \mathrm{~nm} \text { Security interests }\end{array}$ \\
\hline El Salvador & Expressed concern at UNCLOS III in respect of military activities in the EEZ \\
\hline Estonia & $\begin{array}{l}\text { Warships and research vessels must announce their passage } 48 \text { hours } \\
\text { in advance; authorization for nuclear-powered ships must be applied } \\
\text { for } 30 \text { days prior to their passage }\end{array}$ \\
\hline Finland & $\begin{array}{l}\text { Warships and governmental ships have to announce their passage } \\
\text { in advance }\end{array}$ \\
\hline Gambia & $\begin{array}{l}\text { Asserts the right to prohibit navigation in certain areas of its } \\
\text { continental shelf }\end{array}$ \\
\hline Greece & $\begin{array}{l}\text { Claims only a } 6 \mathrm{~nm} \text { territorial sea but } 10 \mathrm{~nm} \text { of airspace for air traffic } \\
\text { control purposes }\end{array}$ \\
\hline Grenada & Warships require prior authorization \\
\hline Guinea & $\begin{array}{l}\text { Taking photographs and transporting toxic or hazardous materials } \\
\text { are considered criminal offences }\end{array}$ \\
\hline Guyana & Warships have to announce their passage in advance \\
\hline
\end{tabular}

Table 1 (Continued)

\begin{tabular}{|c|c|}
\hline State & Type of Rights Asserted \\
\hline Haiti & $\begin{array}{l}\text { Passage prohibited to ships carrying waste or materials with an inherent health } \\
\text { or envitonmental hazard; prohibition of the passage of all vessels carrying } \\
\text { waste or materials that are environmentally tharmful or detrimental to health; } \\
\text { furthermote claims the right to exercise the control tequired in the EEZ in } \\
\text { order to ensure gavigational safety and prevent violations of financial, } \\
\text { customs, health and environmental protection regulations; CZ24 nm } \\
\text { Security interests }\end{array}$ \\
\hline India & $\begin{array}{l}\text { Warships have to announce their passage in advance; prior consent required } \\
\text { for military exercises and manoeuvres in the EEZ and on the continental } \\
\text { shelf; CZ } 24 \mathrm{~nm} \text { Security interests }\end{array}$ \\
\hline Indonesia & $\begin{array}{l}\text { Warships and all vessels other than merchant ships must announce their } \\
\text { passage in advance; within } 100 \text { nin ships are not allowed to stop, anchor or } \\
\text { cruise 'without legitimate cause' }\end{array}$ \\
\hline Iran & $\begin{array}{l}\text { Warships, submarines, nuclear-powered ships and ships carrying nuclear or } \\
\text { other hazardous materials require authorization; prohibition of 'military } \\
\text { activities and practices' in the EEZ and on the continental shelf; CZ } 24 \mathrm{~nm} \\
\text { Security interests }\end{array}$ \\
\hline Latvia & Reserves the right to regulate the passage of Warships \\
\hline Libya & $\begin{array}{l}\text { Innocent passage to be announced in advance and allowed during daylight } \\
\text { hours only; four exclusion zones. }\end{array}$ \\
\hline Lithuania & Warships require prior authorization if this is required by the flag State \\
\hline Malaysia & $\begin{array}{l}\text { Prior consent to military exercises and manoeuvres in the EEZ and on the } \\
\text { continental shelf }\end{array}$ \\
\hline Maldives & $\begin{array}{l}\text { Warships require prior authorization; with regard to the EEZ, acknowledge } \\
\text { only the right of innocent passage; make entry of fishing and research vessels } \\
\text { into the EEZ conditional upon prior consent }\end{array}$ \\
\hline Malta & Asserts the claim for warships to obtain prior authorization \\
\hline Mauritania & $\begin{array}{l}\text { Reserves the right to restrict navigation and aviation in or above the EEZ if } \\
\text { this is necessary for teasons of national Security }\end{array}$ \\
\hline Mauritius & $\begin{array}{l}\text { Warships must announce their passage; apparently makes the passage of } \\
\text { warships and submarines through the } \mathrm{EEZ} \text { condirional upon prior approval }\end{array}$ \\
\hline Myanmar & $\begin{array}{l}\text { Warships tequire prior authorization; claims the right to restrict the freedom } \\
\text { of navigation and overflight in its exclusive economic zone; CZ } 24 \mathrm{~nm} \\
\text { Security interests }\end{array}$ \\
\hline Namibia & $\begin{array}{l}\text { Claims sovereign rights with regard to financial, customs, immigration and } \\
\text { health regulations in the EEZ as well }\end{array}$ \\
\hline Nicaragua & $\begin{array}{l}25 \mathrm{~nm} \text { Security interests. } 15 \text { days advance notification for warships and } \\
\text { military aircraft, seven days for civilian traffic }\end{array}$ \\
\hline North Korea & $\begin{array}{l}62 \mathrm{~nm} \text { Military zone } 50 \mathrm{~nm} \text { seaward of the territorial sea. All ships and } \\
\text { aircraft require prior approval }\end{array}$ \\
\hline Oman & $\begin{array}{l}\text { Warships, nuclear-powered ships, submarines and ships carrying hazardous } \\
\text { loads tequire prior authorization }\end{array}$ \\
\hline Pakistan & $\begin{array}{l}\text { Warships require prior authorization; supertankers, nuclear-powered ships } \\
\text { and ships carrying nuclear materials sare required to announce their passage in } \\
\text { advance; claims authority to regulate transit through parts of the EEZ and } \\
\text { enact and enforce all regulations required for controlling activities in the EEZ; } \\
\text { CZ } 24 \text { nm Security interests }\end{array}$ \\
\hline
\end{tabular}


Table 1 (Continued)

\begin{tabular}{|c|c|}
\hline State & Type of Rights Asserted \\
\hline Peru & $\begin{array}{l}\text { Prior consent to military exercises and manoeuvres in the EEZ and on the } \\
\text { continental shelf }\end{array}$ \\
\hline Philippines & $\begin{array}{l}\text { Expressed concern at UNCLOS III in respect of military activities } \\
\text { in the EEZ }\end{array}$ \\
\hline Poland & Reserves the right to regulate the passage of Warships \\
\hline Portugal & With regard to the EEZ, acknowledges only the right of innocent passage \\
\hline Romania & Reserves the right to regulate the passage of warships \\
\hline $\begin{array}{l}\text { São Tomé } \\
\text { and Príncipe }\end{array}$ & Reserves the right to regulate the passage of warships \\
\hline Saudi Arabia & $\begin{array}{l}\text { Reserves the right to regulate the passage of nuclear-powered ships; } \mathrm{CZ} \\
18 \mathrm{~nm} \text { Security interests and navigation }\end{array}$ \\
\hline $\begin{array}{l}\text { Senegal } \\
\text { Seychelles }\end{array}$ & $\begin{array}{l}\text { Expressed concern at UNCLOS III in respect of military activities in the EEZ, } \\
\text { Warships are reguired to announce their passage in advance }\end{array}$ \\
\hline Slovenia & $\begin{array}{l}\text { Warships are required to announce their passage in advance } \\
\text { Reserves the right to regulate the passage of warships }\end{array}$ \\
\hline Somalia & Warships require prior authorization \\
\hline South Korea & $\begin{array}{l}\text { Warships and government ships have to announce their passage three } \\
\text { days in advance }\end{array}$ \\
\hline Sri Lanka & Warships requite prior authorization; CZ $24 \mathrm{~nm}$ Security interests \\
\hline $\begin{array}{l}\text { St Vincent and } \\
\text { Grenadines }\end{array}$ & Warships require prior authorization \\
\hline Sudan & $\begin{array}{l}\text { Warships require priot authorization; the right of innocent passage may be } \\
\text { suspended for security reasons; CZ } 18 \mathrm{~nm} \text { Security interests }\end{array}$ \\
\hline Syria & Warships require prior authorization; $41 \mathrm{~nm}$ Security interests \\
\hline $\begin{array}{l}\text { United Arab } \\
\text { Emirates }\end{array}$ & $\begin{array}{l}\text { Warships tequire prior authorization; nuclear-powered ships and } \\
\text { ships with-nuclear or hazardous loads must announce their passage in } \\
\text { advance; CZ } 24 \mathrm{~nm} \text { Security interests }\end{array}$ \\
\hline Uruguay & Asserts the right to prohibit military exercises in the EEZ \\
\hline Venezuela & $15 \mathrm{~nm}$ National and security interests \\
\hline Vietnam & $\begin{array}{l}\text { Warships require authorization to be applied for at least } 30 \text { days prior to } \\
\text { passage; passage restricted to three warships at a time; CZ } 24 \text { nm Security } \\
\text { interests. Submarines are required to navigate on the surface and to show } \\
\text { their flag; aircraft are not allowed to land on board ships or be launched from } \\
\text { them; on-board weapons have to be set in 'non-operational' mode prior to } \\
\text { the entry into the zone }\end{array}$ \\
\hline Yemen & $\begin{array}{l}\text { Warships require prior authorization; nuclear-powered ships or ships } \\
\text { carrying nuclear materials must announce their passage in advance; } \mathrm{CZ} \\
24 \mathrm{~nm} \text { Security interests }\end{array}$ \\
\hline Yugoslavia & Warships must announce their passage 24 hours in advance \\
\hline
\end{tabular}

- Derived principally from a number of tables contained in Germany, Commander's Handbook: Legal Base for the Operations of Naval Forces, additional material added by the author.

\section{(b) Proliferation Security Initiative}

The Proliferation Security Initiative (PSI) was announced in Krakow, Poland on 31 May 2003 by President George W Bush. ${ }^{30}$ It was initially a cooperative venture

30 President Bush stated: 'When weapons of mass destruction or their components are in transit, we must have the means and the authority to seize them. So today I announce a new effort to fight between 11 States, ${ }^{31}$ but has gradually widened its support base to include a number of additional States, including Russia. ${ }^{32}$ In addition to this direct support, the PSI received tacit approval from States attending an international conference directed at international security arrangements. This was demonstrated at the recent first anniversary meeting in Krakow on 31 May-1 June 2004, which was attended by over 60 States. ${ }^{33}$

The thrust of the PSI is to prevent the proliferation of Weapons of Mass destruction (WMD) by sea, land, and air, although within the scope of this paper, only the marine aspect of the Initiative will be considered. ${ }^{34}$ The PSI is not a treaty, but rather a statement of intention on the part of participating States, and of itself, it does not create formally binding obligations at international law. Participating States have agreed to abide by a set of interdiction principles, set out in a formal Statement of Interdiction Principles. The interdiction principles indicate that States will undertake effective measures to combat the proliferation of WMD, delivery systems or related materials, ${ }^{35}$ cooperate on information exchange and coordination of activities to combat such proliferation, ${ }^{36}$ and review domestic and, if necessary, international law to strengthen these efforts. ${ }^{37}$

proliferation called the Proliferation Security Initiative. The United States and a number of our close allies, including Poland, have begun working on new agreements to search planes and ships carrying suspect cargo and to seize illegal weapons or missile technologies. Over time, we will extend this partnership as broadly as possible to keep the world's most destructive weapons away from out shores and out of the hands of our common enemies.' Available at http://www.whitepages.gov/news/releases/ 2003/05/20030531-3.html.

31 Australia, France, Germany, Italy, Japan, the Netherlands, Poland, Portugal, Spain, the UK, and the US. $\quad 32$ Canada, Denmark, Norway, Russia, Singapore, and Turkey. Krakow, 31 May - 1 June 2004, available at htrp: $/$ www.dfateration Security lnitiative Meeting chairmans_statement 040601 htm

34 See generally, M Byers, 'Policing the High Seas: The Proliferation Security Initiative' (2004) 98 AJIL. 526; I P Barry, 'The Right of Visit, Search and Seizure of Foreign Flarity Inicitive' (2004) 98 A). 526; I P Barry, 'The Right of Visit, Search and Seizure of Foreign Flagged Vessels on the High (2004) 33 Hofstra Lustomary Intern Review 299.

35) 33 Hotstra Law Review 299. 35 Paragraph 1 of the Statement of Interdiction Principles provides: 'Undertake effective measures, either alone or in concert with other states, for incerdicting the transfer or transport of WMP. their delivery systems, and related mateilals to and from states and non-state actors of proliferation concern. "States or non-state actors of proliferation concern" generally refers to those countries or entities that the PSI parcicipants involved establish should be subject to interdiction activities because they are engaged in proliferation through: (1) efforts to develop or acquire chemical, biological, or nuclear weapons and associated delivery systems; or (2) transfers (either selling, receiving, or facilitating) of WMD, their delivery systems, or related materials.' Available at http://www.dfat.gov.au/ globalissues/psi/psi_statement.hrml.

${ }_{36}$ ibid, para 2 provides: 'Adopt streamlied procedures for rapid exchange of relevant information concerning suspected proliferation activity, protecting the confidential character of classified information provided by other states as part of this initiative, dedicate appropriate xesources and efforts to interdiction operations and capabilities, and maximize coordination among participants in interdiction effors.'

${ }^{37}$ ibid, para 3 provides: 'Review and work to strengthen their relevant national legal authorities where necessary to accomplish these objectives, and work to strengthen when necessary relevant international laws and frameworks in appropriate ways to support these commitments.' 
In terms of specific circumstances when interdiction will take place, the PSI provides a number of instances, and these are worth extracting:

Take specific actions in support of interdiction efforts regarding cargoes of WMD, their delivery systems, or related materials, to the extent their national legal authorities permit and consistent with their obligations under international law and frameworks, to include: ...d. To take appropriate actions to (1) stop and/or search in their internal waters, territorial seas, or contiguous zones (when declared) vessels that are reasonably suspected of carrying such cargoes to or from states or non-state actors of proliferation concern and to seize such cargoes that are identified; and (2) to enforce conditions on vessels entering or leaving their ports, internal waters or territorial seas that are reasonably suspected of carrying such cargoes, such as requiring that such vessels be subject to boarding, search, and seizure of such cargoes prior to entry. ${ }^{38}$

These categories were effectively widened in 2004, with bilateral agreements between the US on the one hand, and initially Liberia and Panama on the other, and subsequently also with Belize, Cyprus, the Marshall Islands, and Croatia, with a view to permitting US vessels to stop and search suspect vessels flagged in these countries. ${ }^{39}$ Liberia and Panama will not function as PSI States, but, in certain circumstances, they have agreed to allow the US to inspect their flag vessels. ${ }^{40}$

The PSI has also been the subject of consideration by the UN Security Council. On 28 April 2004, the Security Council unanimously adopted Resolution 1540 on the prevention of the proliferation of WMD to non-State actors. The

38 Available at http://www.dfat.gov.au/globalissues/psi/psi_statement.html.
${ }_{39}$ Agreement between the Government of the United States of America and the Government of the Republic of Liberia Concerning Cooperation to Suppress the Proliferation of Weapons of Mass Destruction, their Delivery Systems, and Related Materials by Sea, done at Washington DC on 11 February 2004, entered into force 9 December 2004: available at http://www.state.gov/ $\mathrm{dnp} / \mathrm{trty} / 32403 \mathrm{htm}$. Amendment to the Supplementary Arrangement between the Government of the United States of America and the Government of the Republic of Panama to the Arrangernent between the Government of the United States and the Government of Panama for Support and Assistance from the United States Coast Guard for the National Maritime Service of the Ministry of Government and Justice, done at Washington DC on 12 May 2004, entered into force 1 December 2004: available at hetp: $/ /$ www.state.gov/t/np/trty/32858.htm; Agreement Between the Government of the United States of America and the Government of Belize Concerning Cooperation to Suppress the Proliferation of Weapons of Mass Destruction, Their Delivery Systems, and Related Materials By Sea, done at Washington DC on 4 August 2005: available at http://www.state.gov/ t/np/trty/ 50809.htm; Agreement Between the Government of the United States of America and the Government of the Republic of Cyprus Concerning Cooperation to Suppress the Proliferation of Weapons of Mass Destruction, Their Delivery Systems, and Related Materiais By Sea, done at Washington DC on $25 \mathrm{July} 2005$ : available at htt: $/ /$ www.state.gov/t/np/triy/50274.htm; Areement between the Government of the United States of America and the Government of the Republic of Croatia concerning cooperation to suppress the proliferation of weapons of mass destruction, their delivery systems, and related materials, done at Washington DC on 1 June 2005: available at http://www.state.gov/t/mp/trty/47086.hm; Agreement Between the Government of the United States of America and the Government of the Republic of the Marshall Islands Concerning Cooperation to Suppress the Proliferation of Weapons of Mass Destruction, Their Delivery Systems, and Related Materials by Sea, done at Honolulu on 13 August 2004, entered into force on 24 November 2004: available at http: $/ /$ www.state.gov/t/np/trty $/ 35237 . \mathrm{htm}$.

40 Liberia will also have the right to inspect US flag vessels, but it is unlikely this right will be exercised.
Resolution provided that States could take all measures consistent with international law to prevent the proliferation of WMD, and that States were under an obligation to ensure that such weapons did not fall into the control of non-State actors. Significantly, there is no reference to interdiction of vessels, ${ }^{41}$ so the Resolution falls short of the range of measures contemplated within the PSI, however it is clear that the Resolution would render unlawful the shipping of weapons in the circumstances contemplated by the PSI.

Upon their face, these controls do not provide a basis for a coastal State to assert jurisdiction over a passing vessel in its territorial sea for the purposes of the PSI. The matters of which Article 21 permits regulation are clearly restricted to matters pertaining to the safe navigation of the ship, the protection of the surrounding marine environment, and the maintenance of customs and immigration controls of the coastal State. Unless there was a clear intention to import WMD illegally into the coastal State, which could be accomplished when the vessel came alongside in any case, there is no authority that can be drawn from Article 21 to assist coastal States in the implementation of the PSI.

Other articles in the LOSC may be of more utility. Article 19 requires that a ship's passage cannot be prejudicial to the peace, good order or security of the coastal State, and that a tange of activities that fall outside this requirement be explicitly listed, including 'any other activity not having a direct bearing on passage'. ${ }^{42}$ Clearly, the delivery of WMD to terrorists may well be highly prejudicial to the peace, good order and security of a coastal State, and an argument could be made that such a passage is therefore not innocent, and the restrictions on coastal State authority over the passing vessel are removed.

The ability of a coastal State to close territorial waters for essential security purposes on a temporary basis will not assist the PSI. Such closures are to be nondiscriminatory in their application, and clearly this is not possible with the PSI. The PSI's objective is to interdict suspect vessels, not to institute what resembles a blockade and compel the inspection of every passing ship. Further, Article 25(3) is intended to clear areas of the sea temporarily, not to authorize an inspection regime. 43

Coastal State criminal jurisdiction, which would usually encompass preparations to undertake terrorist activities, can also be awakened under Article 27 of the LOSC for vessels passing through the territorial sea. This can occur in four circumstances:

(a) if the consequences of the crime extend to the coastal State;

(b) if the crime is of a kind to disturb the peace of the country or the good order of the territorial sea;

4. This omission was at the request of China.

42 LOSC, Article 19(2) also provides, inter alia: 'Passage of a foreign ship shall be considered to be prejudicial to the peace, good order or security of the coastal State if in the territorial sea it engages in or political independ or political independence of the coastal State, or in any other manner in violation of the principles of 
(c) if the assistance of the local authorities has been requested by the master of the ship or by a diplomatic agent or consular officer of the flag State; or

(d) if such measures are necessary for the suppression of illicit traffic in narcotic drugs or psychotropic substances. ${ }^{44}$

Of the categories above, only (a) and (b) will be of direct relevance to the PSI, because if the master or flag State seeks assistance as in (c), then there is no issue of legality. For (a) and (b), it may be that conspiracy to commit a terrorist act and preparatory steps towards such an act are criminal matters, the consequences of which might extend to the coastal State, or disturb its peace or good order. This would then potentially invoke coastal State jurisdiction. However, the materials may be intended for a third State. This nullifies Article 27, which is specific to the coastal State.

For transit passage and archipelagic sea lanes passage, the same concerns apply save that such passage cannot be interrupted for any reason, not even the essentia security concerns of the coastal State. This would make the stopping of a vessel in an international strait or archipelagic sea lane of greater significance. Further, the categories of coastal State law applicable to such vessels, as described in Article 42, are more limited than those for innocent passage. However, Article 39 does require vessels to refrain from any violation of the principles of the UN Charter, as in Article 19, so the above discussion there would similarly be applicable. 45

The PSI also includes interdiction within the contiguous zone of a participating coastal State. This raises additional issues with respect to freedom of navigation, because whilst vessels in the territorial sea are obliged to observe the regime of innocent passage or be subject to the wider law of the coastal State, the contiguous zone is unfettered by such concerns. Were WMD destined to be imported into the coastal State for use in a terrorist attack, it would seem to fall clearly within the rubric of prevention of infringement of customs and, in certain circumstances, possibly immigration ${ }^{46}$ under Article 33 . The coastal State could therefore argue a right to stop, search, and seize was necessary to uphold its customs laws, and prevent the delivery of highly dangerous and undesirable materials to its territory.

A more difficult situation arises where the WMD are destined for another State. It would not be open to a coastal State to assert that its customs laws were to be infringed by a passing vessel carrying WMD, as the vessel's master might never have had any intention to enter the territorial sea of the coastal State. It would seem an unreasonable adaptation of Article 33 to have it include not mere prevention of infringement of customs of the coastal State, but of other States as well.

44 LOSC, Article 27(1)

45 LOSC, Articles 39 and 42 apply to transit passage. For archipelagic sea lanes passage, Article 54 provides: 'Articles 39, 40, 42 and 44 apply mutatis mutandis to archipelagic sea lanes passage'. 46 Immigration laws might pertain to a situation where terrorists accompanied the WMD aboard
the ship.
This is particularly the case given the freedom of navigation guaranteed for vessels in the contiguous zone, as a foreign flag vessel will have breached no law of the coastal State, and should be entitled to transit through the zone without being interfered with.

\section{(c) Environmental security}

A number of States have also sought to assert the right to deny passage to vessels carrying ultra-hazardous cargoes, most notably nuclear materials for reprocessing or disposal, through not only their territorial sea, but even their EEZ. These States have often been motivated by particular incidents, where vessels have been likely to pass through their waters on planned voyages between other States. Such voyages between Europe and Japan have elicited responses from States in Africa, South America, and the South Pacific. ${ }^{47}$

The LOSC provides little direct assistance for States who wish to assert the right to deny passage to vessels carrying ultra-hazardous cargoes. There is no indication in the LOSC of any restriction that can be placed on navigation in the EEZ based upon the nature of the cargo. Indeed, the LOSC appears to indicate that the reverse situation is the case; that is, ships carrying hazardous cargoes can navigate freely. This can be seen in respect of the exercise of innocent passage for ships carrying nuclear or other hazardous materials in Article 23:

Foreign nuclear-powered ships and ships carrying nuclear or other inherently dangerous or noxious substances shall, when exercising the right of innocent passage through the territorial sea, carry documents and observe special precautionary measures established for such ships by international agreements.

Rather than indicate duties owed to the coastal State, and the option of that State to deny passage, Article 23 indicates that special precautionary measures drawn from other instruments ought to be complied with. No similar provision exists for the EEZ.

The rationalization for States seeking to exclude is based upon their jurisdiction in the EEZ over environmental matters. It is argued by these States that the ultrahazardous nature of the cargo poses such a threat to the environment that they have a right to prevent the possibility of irreparable harm occurring. At the very least, they have a right to be notified of a voyage carrying such cargo, if only to be prepared to respond appropriately to an accident or other disaster, should one occur. Examples of State practice from States that take the view that freedom of navigation can be circumscribed because of a ship's cargo, cover a range of situations. As a result of the break-up of the oil tanker Prestige in November 2002, Spain and France asserted that they would undertake inspections of single hulled

${ }^{47}$ See eg J M Van Dyke, 'Sea Shipment of Japanese Plutonium under International Law' (1993) 24 ODIL 399; E J Molenaar, Coastal Jurisdiction over Vessel Source Pollition (Kluwer Law International, The Hague 1998). 
oil tankers in excess of 15 years old passing through their EEZs, and if the vessels were found to be unseaworthy, they would not be permitted to remain in the EEZ.48

Further examples can be drawn from international reactions to shipments of radioactive materials around the world, particularly since the 1990s. The voyages of the Pacific Pintail, Pacific Teal, and Pacific Swan and the Atatsuki Maru carrying highly radioactive material attracted protests from a significant number of States, and led States such as Argentina, Chile, Antigua and Barbuda, Colombia, Dominican Republic, New Zealand, South Africa, and Mauritius to purport to exclude vessels carrying radioactive ultrahazardous cargo from their EEZs. Voyages were also condemned by Caricom, representing the Caribbean States, and the South Pacific States. ${ }^{49}$ States who have asserted that they will not permit nuclear cargo vessels in the territorial sea or EEZ are noted in Table 2, below.

\section{Conclusion}

The table below indicates that a sizeable number of States seek to impose restrictions in respect of security in their adjacent waters. These States represent

Table 2: States that have objected to nuclear ships passing though their Territorial Sea or EEZ a

\begin{tabular}{ll}
\hline Antigua and Barbuda & Nauru \\
Argentina & New Zealand \\
Brazil & Oman \\
Chile & Papua New Guinea \\
Colombia & Peru \\
Dominican Republic & Philippines \\
Egypt & Puerto Rico \\
Fiji & Saudi Arabia \\
Guinea & Singapore \\
Indonesia & South Africa \\
Iran & Venezuela \\
Haiti & Yemen \\
Kiribati & \\
Malaysia & \\
Malta & \\
\hline & \\
" Derived from Roscini, above note 49, and Van Dyke, above \\
note 49.
\end{tabular}

48 See J M Van Dyke, 'Military Ships and Planes operating in the Exclusive Economic Zone of Another Country' (2004) 28 Marine Policy 29, 37.

49 See generally M Roscini, 'The Navigational Rights of Nuclear Ships' (2002) 15 Leiden Journal of International Law 251; J M Van Dyke, 'Balancing Navigational Freedom with Environmental and approximately one third of the international community, and between one third and one half of States possessing a sea coast. While such a proportion would not reach the level of support indicated by the International Court of Justice in the North Sea Continental Shelf Cases ${ }^{50}$ to indicate the presence of customary international law, it still represents a sizeable body which does not accept that the LOSC does not restrict freedom of navigation for security reasons, beyond the limited exception in Article 25(3).

It is interesting to note that many States which strongly support freedom of navigation are also supporters of the PSI. Whilst the PSI does not purport to be contrary to international law and does not create a 'security zone' for warship reporting and authorization, it does encourage participating States to take action against suspect vessels in their territorial sea and contiguous zone. Such measures are designed to prevent the transport of WMD and related material, essentially for the security of the coastal State and its fellow PSI participants. The concern arising out of this is that the PSI States do not figure in Table 2, and their support for the PSI may be seen by many as a limited increase to the number of States that place security-based restrictions on freedom of navigation through their waters. Such an increase would take the level of States interested in placing security restrictions on navigation to over half of States possessing a sea coast. However, in its present form, with the lack of a binding treaty, and the reiteration that it is consistent with international law, the PSI does not exode the position of the maritime powers with respect to security notification. As it is not based on treaty, the PSI could not be said to be strictly within the traditional corpus of international law, and what little can be traced to traditional sources, such as Security Council Resolution 1540, is stated to be carried out in accordance with international law. Unless and until an actual interception, without some other ground based on flag or port State control, takes place and the maritime powers assert the legality of their actions, those States seeking security notification will remain without concrete action upon which to base their objections.

Given the small number of PSI interceptions to date, the erosion of navigational freedoms may be some time coming, and more than likely will not come at all. The PSI States are also working hard to ensure that alternative measures are available that do not do such potential violence to traditional freedom of navigation. The moves towards enhancing the SUA Convention ${ }^{51}$ in the latter half of 2005 and the conclusion of bilateral interception agreements between the US and

Security Concerns' (2003) Colorado Journal of International Environmental Law and Policy 19; J M Van Dyke, 'The Legal Regime Governing Sea Transport of Ultrahazardous Radioactive. Materials' (2002) 33 ODIL 77.

so [1969] ICJ Rep 3.

51 See Convention for the Suppression of Unlawful Acts against the Safety of Maritime Navigation, 1988, 1678 UNTS 221; Protocol for the Suppression of Unlawful Acts Against the Safety of Fixed Platforms Located on the Continental Shelf, 1988, 1678 UNTS 304; A Conference to amend the Convention and its. Protocol adopted amendments on 14 October 2005. See hittp.//www.imo. $\mathrm{org} /$ Conventions/Maniframe.asp?topic_id $=2598$ doc_id $=686$ 
States representing almost 60 per cent of the world's shipping tonnage are all other avenues to achieve the PSI's objectives, ${ }^{52}$ without undermining the fabric of international law that supports freedom of navigation.

Nevertheless, the PSI coupled with the significant number of States asserting a security jurisdiction, and the body of States who have objected to the passage of ships carrying ultrahazardous cargoes, all place pressure on freedom of navigation. States asserting jurisdictions of this nature are each asserting that in certain circumstances the freedom of navigation of vessels ought to be circumscribed for reasons related to the interest of protecting their territory or waters from harm. If the number of States asserting a right to deal with security measures continues to grow, be it in the context of military, environmental or security concerns regarding the transfer of WMD to non-state actors, then navigational freedoms may begin to erode, and a new creeping of jurisdiction may take root.

52 See above note 39 . 


\section{University Library}

\section{- M M I N E R VA A gateway to Melbourne's research publications}

Minerva Access is the Institutional Repository of The University of Melbourne

Author/s:

KAYE, S

Title:

Freedom of navigation in a post 9/11 world: Security and creeping jurisdiction

Date:

2006

Citation:

KAYE, S. (2006). Freedom of navigation in a post 9/11 world: Security and creeping jurisdiction. The Law of the Sea: Progress and Prospects, (1), pp.347-364. Oxford University Press.

Persistent Link:

http://hdl.handle.net/11343/25569 